\title{
Incidence of Violence Among the Elderly in a Family Health Center OOAGWMan
}

\section{Ankilma do Nascimento Andrade Feitosa ${ }^{1}$, Palloma Batista de Almeida', Ocilma Barros de Quental'} Maura Vanessa Silva Sobreira', Elisangela Vilar de Assis' ${ }^{1}$, Morgana do Nascimento Andrade', Italla Maria Pinheiro Bezerra ${ }^{3}$, Luiz Carlos de Abreu $^{3}$, Hermes Melo Teixeira Batista ${ }^{3}$, Gylmara Bezerra de Menezes Silveira ${ }^{4}$, Sheylla Nadjane Batista Lacerda ${ }^{5}$, Fernando Adami ${ }^{6}$

\section{Abstract}

Introduction: Violence is not considered a stigma of contemporary society, as it accompanies the man since ancient times and manifests itself in different ways and circumstances in each period. It is a sociohistorical phenomenon that accompanies the whole mankind experience, although this has never been accepted as something intrinsic to the human condition.

Objective: Verify the incidence of violence among the elderly in Brazil.

Methods: Exploratory and descriptive field research, with a quantitative approach, conducted in a Family Health Center in Cajazeiras, Paraíba, Brazil. Data was collected in March and April 2014, using an instrument validated by the multicenter study Health, Well-Being, and Aging (SABE). This study was approved by the Ethics Committee of Research from University Santa Maria (FSM), under the Certificate of Submission for Ethical Appraisal (CAAE) n. 24982213.7.0000.5180.

Results: The sample presented a mean age of 73.68 years old, with a predominance of women $(69.9 \%)$. We analyzed demographic data relative to age, gender, marital status, educational level, income, and hostility. The data on the prevalence of violence among the elderly indicate that the most frequent cases of mistreatment were those involving psychological or verbal violence $(23.0 \%)$, followed by financial violence $(10.6 \%)$, and physical violence $(4.4 \%)$.

Conclusion: It was found that any elderly individual may be victim of violence, especially when taking into account that this population group has been neglected both by the State and civil society.
1 University Santa Maria. Cajazeiras (PB), Brazil.

2 Master in neuroscience by UFPB. João Pessoa (PB), Brazil.

3 University of Medicine $A B C$, Santo André, SP, Brazil.

4 Nurse at the Cariri Regional Hospital. Rua Catulo da Paixão Cearense, S/N. Juazeiro do Norte, CE, Brazil.

5 Health Sciences by Faculty of Medicine $A B C$ - FMABC. Cajazeiras (PB), Brazil.

6 Community Health Department. Faculty of Medicine ABC. Santo André, SP, Brazil.

\section{Contact information:}

\section{Luiz Carlos de Abreu.}

Laboratório de Delineamento de Estudos e Escrita Científica. Departamento de Saúde da Coletividade. Disciplina de Metodologia Científica.

Address: Faculdade de Medicina do ABC. Santo André, SP. Brasil. Av. Príncipe de Gales, 821, Santo André, SP CEP 09060650.

$\equiv$ Luiz.abreu@gmail.com

\section{Keywords}

Aging; Family Health Strategy; violence against the elderly. 


\section{Introduction}

Violence is not considered a stigma of contemporary society, as it accompanies the man since ancient times and manifests itself in different ways and circumstances in each period. It is a socio-historical phenomenon that accompanies the whole mankind experience, although this has never been accepted as something intrinsic to the human condition. [1]

The theme of violence has been the focus of numerous publications and forums about human rights, being noted because of the inordinate increase of the notifications in any medium without definition of public, and generally, associated to economic, social and cultural factors, ranging from domestic violence to major conflicts and reaching millions of people worldwide, thus, constituting a public health problem. [2]

The violence against the elderly stands out, which according to the World Health Organization (WHO) [2] is defined as an act of involvement or omission, which can be both intentional or unintentional. The mistreatment can be physical or psychological in nature or may be of financial or material order. Whatever the type of abuse, it will result in suffering, injury or pain, loss or violation of human rights and reduced quality of life of the elderly.

The most vulnerable seniors are those with physical or mental dependence, especially when they have cognitive deficits, sleep disturbances, incontinence and mobility difficulties and in need of intensive care to perform daily activities. Among other risk factors we may indicate the excessive consumption of alcohol and / or other drugs by the caregiver and even situation of mental health problems if they are under high stress levels due to their everyday life. [3]

However, the highest incidence of abuse occurs at the household level and involves the family itself, including sons-in-law, daughters-in-law, children and grandchildren; this leads most of the elderly not to seek medical help. These aggressions can be identified through home visits by health teams; this work is developed by professionals dedicated to promoting health and well-being who operate within the Family Health Strategy (ESF), which provides resources to detect violence against the elderly. [3]

It is the responsibility of the health professionals to know the elderly population in their area, especially the older ones, and have the sensitivity and care to detect signs that a senior may be undergoing mistreatment and violence. The professional must identify, notify cases and report suspicious cases. Failure to report cases of violence is a crime.

Given this issue, the following research question emerged: What is the incidence of violence against the elderly in a Family Health Center in Cajazeiras $(\mathrm{PB})$ ?

Thus, this study aims to verify the incidence of violence among the elderly in Cajazeiras, PB, Brazil.

\section{Methods}

This is a study of field, exploratory and descriptive, with a quantitative approach, performed with elderly patients from a Family Health Center located in the urban area of Cajazeiras, high sertão of Paraiba.

This Family Health Center (USF) offers health care to the elderly and helps their families face the problems involved in aging both by spontaneous demand and through home visits, a key resource for the promotion of individual's health, particularly when they are unable to attend the USF.

The population consisted of 503 elderly, with data obtained through the community health agents (ACS); only 113 elderly fulfilled the inclusion criteria of this study: age $\geq 65$ years old, being conscious and oriented.

The information obtained through the instrument of collection was analyzed using the Statistical Package for the Social Sciences (SPSS). It was accepted as a significant $p \leq 0.05$. 


\section{INTERNATIONAL ARCHIVES OF MEDICINE \\ Section: Global Health \& Health Policy \\ ISSN: 1755-7682}

The study was approved by the Ethics Committee in Research of the University Santa Maria (FSM) under the General Certificate for Ethics Assessment (CAAE) n. 24982213.7.0000.5180.

\section{Results and Discussion}

The study included 113 elderly people, 78 (69\%) females, 35 (31\%) are male. With regards to marital status, 48 (42\%) are married, 36 (32\%) widowed and $29(26 \%)$ divorced. On the level of education, 83 reported that only write their names, 8 (7\%) seniors get the equivalent of 03 minimum salaries.

The following illustrate the results regarding the incidence of violence among the elderly revealing the frequency and type of abuse, evidenced feelings.

\section{Frequency and type of abuse}

Table 1 shows the frequency and types of abuse suffered by older people, revealing that the most frequent cases of mistreatment were those involving psychological or verbal violence, with 26 occurrences (23.0\%), and the elderly report frequency of 2 to 3 times per month in 22 of them (84.6\%).

The financial violence made a total of 12 events $(10.6 \%)$, with frequency of 2 to 3 times a month in 7 of them (58.3\%). And the less frequent type was the physical violence, with 5 occurrences (4.4\%), and in 3 of them (60\%) this aggression was reported once a month or less.

According to the Brazilian Institute of Geography and Statistics (IBGE) [4], the prevalence of physical abuse was reduced, from $15.51 \%$ in 2011 to $3.33 \%$ in 2013 . Similarly, the prevalence of psychological abuse fell from $29,31 \%$ to $6.66 \%$. There was no significant change on the prevalence of mistreatment among the victims of negligence.

Table 1 demonstrates the prevalence of cognitive impairment and financial dependence in the two groups.

The violence against the elderly is considered one of the most severe forms of aggression during the
Table 1. Decision-making operations/operators, their sensitivity and probable molecular signatures.

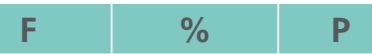

This past year, some of the people around you have yelled at you for no reason?

\begin{tabular}{|l|c|c|c|}
\hline Yes & 26 & 23.0 & 0.01 \\
\hline No & 87 & 77.0 & \\
\hline How often? & & & \\
\hline Every day & 0 & 0 & \\
\hline Two or three times a week & 1 & 3.8 & \\
\hline Once a week & 3 & 11.5 & 0.01 \\
\hline Two or three times a month & 22 & 84.6 & \\
\hline Once a month or less & 0 & 0 & \\
\hline
\end{tabular}

This past year, some of the people around you has used or moved your money without your consent?

\begin{tabular}{|l|c|c|c|}
\hline Yes & 12 & 10.6 & 0.01 \\
\hline No & 101 & 89.4 & \\
\hline How often? & & & \\
\hline Every day & 0 & 0 & \\
\hline Two or three times a week & 0 & 0 & \\
\hline Once a week & 0 & 0 & 0.01 \\
\hline Two to three times a month & 7 & 58.3 & \\
\hline Once a month or less & 5 & 41.7 & \\
\hline
\end{tabular}

This past year, some of the people around you have threatened you when you do not do what shelhe wants?

\begin{tabular}{|c|c|c|c|}
\hline Yes & 6 & 5.3 & 0.0 \\
\hline No & 107 & 94.7 & \\
\hline
\end{tabular}

How often?

\begin{tabular}{|l|l|l|l|}
\hline Every day & 0 & 0 & \\
\hline Two or three times a week & 0 & 0 & \\
\hline Once a week & 1 & 0.9 & 0.01 \\
\hline Two or three times a month & 2 & 1.8 & \\
\hline Once a month or less & 3 & 2.7 &
\end{tabular}

This past year, some of the people around you have been hitting you?

\begin{tabular}{|l|c|c|c|}
\hline Yes & 5 & 4.4 & 0.01 \\
\hline No & 108 & 95.6 & \\
\hline How often? & & & \\
\hline Every day & 0 & 0 & \\
\hline Two or three times a week & 0 & 0 & \\
\hline Once a week & 1 & 20 & 0.01 \\
\hline Two to three times a month & 1 & 20 & \\
\hline Once a month or less & 3 & 60 & \\
\hline
\end{tabular}


$\mathbf{F}$

$\%$

P

This past year, some of the people around you have stolen your money or belongings important for you?

\begin{tabular}{|l|c|c|c|}
\hline Yes & 14 & 12.4 & 0.01 \\
\hline No & 99 & 87.6 & \\
\hline How often? & & & \\
\hline Every day & 0 & 0 & \\
\hline Two or three times a week & 0 & 0 & \\
\hline Once a week & 1 & 7.1 & 0.01 \\
\hline Two to three times a month & 6 & 42.9 & \\
\hline Once a month or less & 7 & 50 & \\
\hline Source: Prepared by the authors. & & \\
\hline
\end{tabular}

process called senescence; inequality is clearly seen in the physical and psychological factors, not counting with the family embarrassment that is observed by the breakdown of trust between the elderly victim of aggression performed by relatives or caregivers. $[5,6]$ It is also noteworthy that many of the elderly are providers for their families and they are still victims of attacks that compromise their status as human beings.

According to studies on this subject that show that there are various forms of violence against the elderly, among which, we highlight: physical, psychological, economic and financial violence. They can occur alone or together with other. [7-9] Psychological violence is directed to verbal or gestural aggression and aims to terrorize the elderly, humiliate, restrict their freedom and isolate them from society, since this kind of violence was the more frequent in the family scope. The physical violence refers to the use of force to compel seniors to do what they do not wish, to hurt them, to cause pain, disability or death. And the financial violence is the improper or illegal exploitation of the elderly or the absence of their consent to use their financial resources and assets.

According to the data presented in this context, many of the forms of violence do not officially reach the institution, setting an underreporting and consequently, the injury to the fidelity of information about this reality in our midst. Given the scarcity of such information about the attacked and attackers, this becomes a delicate situation, mainly because the elderly do not report the suffered abuses and aggressions, because of embarrassment and fear of revenge by their caregivers, who, often are their own abusers. The vast majority of abused seniors victimized by violence do not report these crimes for different reasons, including not realizing the phenomenon as violence or fear of incriminating their relatives. [10]

According to the Elderly Statute, art. 4, "no elderly will be subject of any type of negligence, discrimination, violence, cruelty or oppression and any attack to their rights, being by act or omission will be punished under the law". [11] Regardless of the Elderly Statute, every citizen should be respected. Thus, when the elderly seek health service in case of aggression, it is extremely important that the health professional, including the nursing team, know how to identify what happened in search of solutions to the problem of abuse and negligence. The emergency services and health centers require special attention, as they are the main ports of entry for victims of mistreatment in the Unified Health System (SUS).

Table 1 and figures 1 and $\mathbf{2}$ show that the presence of more people at home seems to be a factor of protection against mistreatment to the elderly.

Elderly people who reported that people use their money without their authorization, on average, have fewer people living with them, an average of 1.75 people $(S D=0.62$ ) versus 3.08 people (SD $=1.49$ ) among those who did not report people fiddling with their money $(p=0.01)$. Those seniors who reported that someone stole them, on average, also have fewer people living with them ( $m=$ 2.14, $S D=1.29 ; p=0.03$ ).

It is observed that about $70 \%$ of the elderly live in situation of poverty or misery. [13] Even those who are poor find themselves obliged to contribute to the family income through the little money they get 
Figure 1: Comparison between the number of people in the household and the number of people that has touched the elderly's money. Cajazeiras, PB, Brazil, 2014.

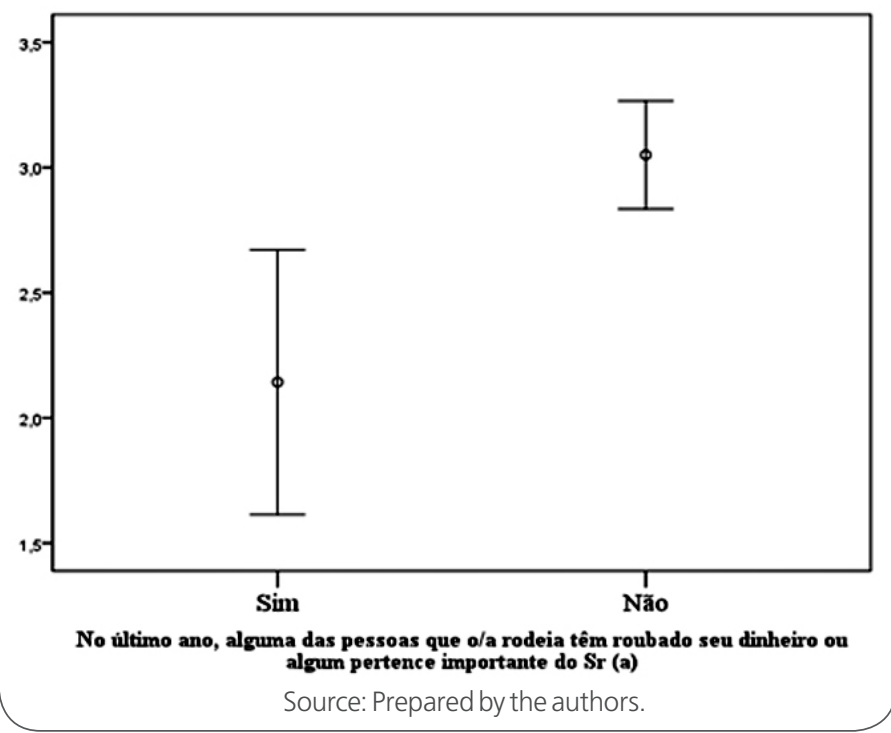

Figure 2: Comparison between the number of people in the household and the number of people that has stolen the elderly's money. Cajazeiras, PB, Brazil, 2014

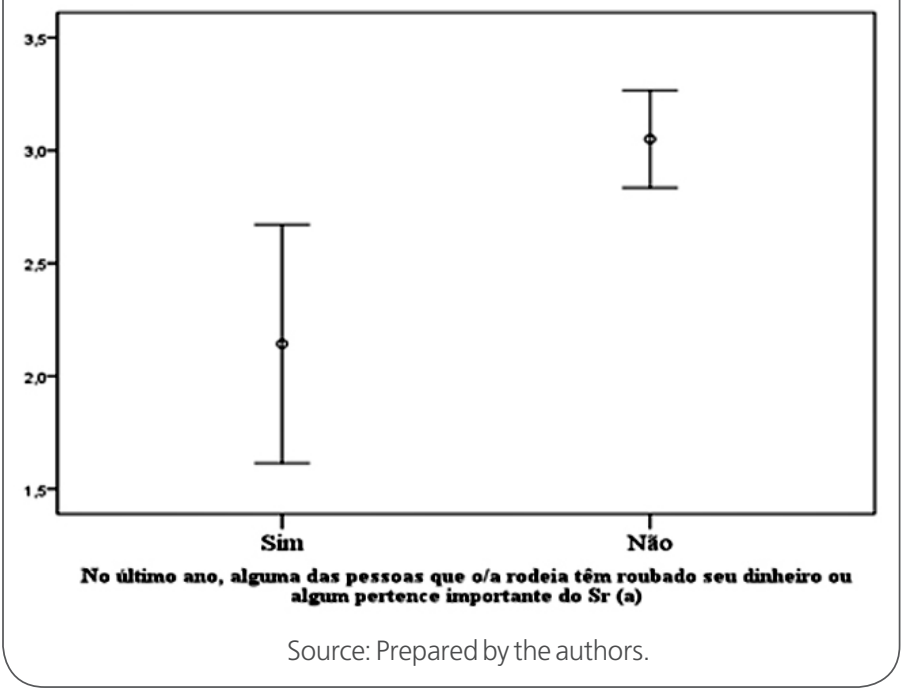

from their retirement or even serve as a "stop" for the family with their little income. In this respect, after retiring, seniors feel inferior and tend to be considered useless and unproductive.

The mistreatment of older people make a total of about $95 \%$ of cases related to financial matters, abuse that occur in the elderly's home and their caretakers. [13]

In this sense, the social security policy, alongside health and welfare, contributes to the expansion of citizenship, as it incorporates the circuit of goods, services and rights enjoyed by a minority, segments of the population traditionally excluded from this midst. [11]

Therefore, it is an unconditional right, that is, free and decentralized, that, by recognizing in the citizens, especially the poorest, the status of creditors of an enormous accumulated social debt, are presented as provision of duty, if not compensation, of the Government. Thus, it does not justify the forecast of impositive counterparts of the poor senior citizen in relation to financial losses through the access condition and enjoyment of assistance which he is entitled to. [11]

\section{Evident feelings}

Table 2 shows some final comments from the interviewed. Only in one case the researchers observed a situation of children abandoning the elderly. In 3 cases the relatives interfered with answers given by the elderly.

In this context, it is stated that, under the mistreatment and negligence of older people in the intra-family settings, there are risk factors such as history of family violence, offender's dependence in relation to the frail elderly, functional disability for self-care, stress of the caregiver, social isolation of the elderly and caregiver, problems in the area of mental health, presence of alcoholics among family members as caretakers. [12] The results of this study also show many elderly people with some kind of addiction or living some situation of social isolation. 
Table 2. Evident feelings. Cajazeiras, PB, Brazil, 2014.

\section{\begin{tabular}{l|l|l|}
$\mathbf{F}$ & $\%$
\end{tabular}}

It was observed, a situation of violence, abandonment and mistreatment of any member of the house against the interviewed?

\begin{tabular}{|l|c|c|c|}
\hline Yes & 1 & 0,9 & 0.01 \\
\hline No & 112 & 99,1 & \\
\hline
\end{tabular}

Description: The children left the elderly and only seek them to get money

Someone else was present during the interview (besides the informant or substitute)?

\begin{tabular}{|l|c|c|}
\hline Yes & 3 & 2,7 \\
\hline No & 110 & 97.3 \\
\hline
\end{tabular}

\section{Description}

The daughter of the female elderly induced the response of the interviewed

The daughter of the male elderly induced his response The granddaughter did not interfere in the answers

At what time and day of the week you find it easier to find the person interviewed, if a new contact is needed?

In the afternoon, every day,

at home

$3 \quad 2.7$

Friday, Saturday and Sunday, anytime

They are at home every day

1

0,9

0.01

Source: Prepared by the authors.

It was observed that violence, abandonment and mistreatment by members of the house in relation to the elderly was negative, considering the margin of 112 elderly (99.1\%) versus $0.9 \%$ of the interviewed $(S D=0.01)$. With regards to the presence of other people at the time of the survey, 110 elderly (97.3\%) responded that there were no other people in the room. As for the future return of the researcher to the home of the elderly and the best time and day to find himlher, the gathering of information points out that 109 participants $(96.5 \%)$ remain in their home every day, only 3 of them (2.7\%) are at home in the afternoon every day and one elderly (0.9\%) is found at home any time on Friday, Saturday and Sunday.

It was found that the most vulnerable seniors are those with physical or mental dependence, es- pecially with cognitive deficits, sleep disturbances, incontinence and mobility difficulties and in need of intensive care in daily activities.

According to the Regency of the law aimed at protecting the elderly and the consequent reduction of violence suffered by him, were established in Brazil, over the last 20 years, some legal provisions of guard for the elderly, including those set forth in the Federal Constitution, providing guidelines for the preparation of the National Health Policy for the Elderly and the Elderly Statute. [11]

As promulgated in the Federal Constitution, the elderly is a subject of rights; Any form of age discrimination is illegal and it is responsibility of the family, society and the State: "the duty to protect the elderly, ensuring their participation in the community, defending their dignity and wellbeing, and ensure their right to life." [3] In this context, there was a significant improvement in the quality of life of older people and reduction of the abuse, since they fit the devices set by the political system.

\section{Conclusion}

In this study, the data related to the incidence of violence among elderly allowed to verify that the most frequent cases of mistreatment were the psychological or verbal violence, the physical violence on its own has the lowest prevalence among the identified types of violence.

For this, the identification of groups of older people who suffer health problems related to violence can help in policy-making and implementation of social programs in a Family health Center (USF), aimed to the multidisciplinary care to fight abuse against the elderly, enabling the adequacy of services to the new demands of aging.

The discussion developed in this study shows itself as very important in the current Brazilian context, where the aging process is not equal for all, and clearly, it becomes much more painful for the poor, 
who do not have access to the Unified Health System (SUS) and dignified conditions of work, neither to social assistance and retirement.

\section{References}

1. Parraga EE. O papel do enfermeiro no atendimento a criança e adolescente vítima da violência sexual [monograph on the internet]. Uruguaiana (RS): Universidade Federal do Pampa; 2010 [cited 2013 Aug 18]. Available from: http://cursos.unipampa. edu.br/cursos/enfermagem/files/2010/09/TCC-Elton.pdf.

2. Organização Mundial da Saúde. Informe mundial sobre la violencia y salud. Genebra: OMS, 2002.

3. Oliveira SC, Leite AC, Monteiro LCA, Pavarini SCL. Violência em idosos após a aprovação do Estatuto do Idoso: revisão integrativa. Rev Eletrônica Enferm [serial on the internet]. 2012 Oct-Nov [cited 2013 Oct 14]; 14(4): 974-82. Available from: http://www. revistas.ufg.br/index.php/fen/article/view/12919/13363.

4. Instituto Brasileiro de Geografia e Estatística. Primeiros resultados definitivos do Censo 2010: população do Brasil é de 190.755.799 pessoas [document on the internet]. Rio de Janeiro: IBGE; 2010 [cited 2013 Dec 3]. Available from: http://censo2010.ibge.gov. br/noticias-censo? $\% 20$ view $=$ noticia $\& i d=1 \& i d n o t i c i a=\% 20$ $1866 \& \mathrm{t}=$ primeiros - resultados-definitivos-censo-2010populacao-brasil-190-755-799-pessoas.

5. Faleiros VP. Violência contra a pessoa idosa ocorrências, vítimas e agressores. Brasília, (DF): Universa; 2007.

6. Machado L, Queiroz ZV. Negligência e maus-tratos. In: FREITAS EV, organizer. Tratado de geriatria e gerontologia. Rio de Janeiro: Guanabara Koogan; 2006. p. 1152-9.

7. Brasil. Envelhecimento e saúde da pessoa idosa. Brasília (DF): Ministérios da Saúde; 2006.

8. Minayo MCS. Violência contra idosos: relevância para um velho problema. Cad Saúde Pública [serial on the internet]. 2003 MayJune [cited 2013 Aug 17]; 19:783-91. Available from: http:// www.scielo.br/pdf/csp/v19n3/15881.pdf.

9. Brasil. O mapa da violência contra a pessoa idosa no Distrito Federal [document on the internet]. Brasília (DF): Tribunal de Justiça do Distrito Federal e dos Territórios; 2013 [cited 2013 Aug 21]. Available from: http://www.tjdft.jus.br/institucional/ imprensa/noticias/arquivos/mapa-da-violencia-contra-o-idoso.

10. Shimbo AY, Labronici LM, Montovani MF. Reconhecimento da violência intrafamiliar contra idosos pela equipe da estratégia saúde da família. Esc Anna Nery Rev Enferm [serial on the internet]. 2011 July-Sep [cited 2013 Oct 17]; 15(3): 506-10. Available from: http://www.scielo.br/scielo.php?script=sci_artte xt\&pid=S1414-81452011000300009.
11. Brasil. Estatuto do Idoso. Brasília (DF): Ministério da Saúde; 2003.

12. Machado L, Queiroz ZV. Negligência e maus-tratos. In: FREITAS EV, organizer. Tratado de geriatria e gerontologia. Rio de Janeiro: Guanabara Koogan; 2002. p. 791-7.

13. Fonseca MM, Gonçalves HS. Violência contra o idoso: suportes legais para intervenção. Interação Psicol [serial on the internet]. 2003 July-Dec [cited 2014 Dec 10]; (2): 121-8. Available from: http://www.egov.ufsc.br/portal/pt-br/conteudo/ viol\%C3\%AAncia-contra-o-idoso-suportes-legais-parainterven\%C3\%A7\%C3\%A30.

\section{Comment on this article:}

\section{$9[8$ in $8+2.9$}

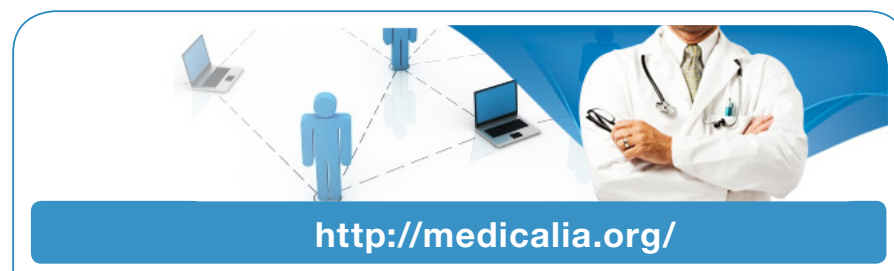

Where Doctors exchange clinical experiences, review their cases and share clinical knowledge. You can also access lots of medical publications for free. Join Now!

\section{Publish with iMedPub}

\section{http://www.imed.pub}

International Archives of Medicine is an open access journal publishing articles encompassing all aspects of medical science and clinical practice. IAM is considered a megajournal with independent sections on all areas of medicine. IAM is a really international journal with authors and board members from all around the world. The journal is widely indexed and classified Q1 in category Medicine. 